\title{
Exploration of Design Innovation for Modern Household Ceramic Products
}

\author{
Li Cai Rang La Mao \\ Jingdezhen Ceramic Institute, Jingdezhen, 333400, China
}

Keywords: Modern household, Ceramic product, Design, Innovation

\begin{abstract}
As China's economic level keeps improving, modern people pay more and more attention to living quality and increasing pursue art ad spirit world. China belongs to a large country in terms of culture. Spiritual culture has a long history. Ceramic art is widely applied and develops. In recent years, domestic ceramic products have gradually been used by common people's homes. They further own modern art atmosphere and cultural aesthetics. Modern household ceramic products greatly enrich people's spiritual culture world.
\end{abstract}

\section{Introduction}

While material culture develops in human society, spiritual civilization also becomes an indispensable part of modern people in life. With continuous development and progress of China's science and technology, modern household ceramic products become richer and more all-round. As people's living quality improves continually, people's requirements for ceramic products also increase. The development of anything cannot be separated from innovation. China owns ceramics culture with a long history. The design of ceramic products is greatly influenced by traditional culture, so the design lacks certain innovation. Thus, innovative design idea of China's ceramic products lags far behind western countries. At present, China's modern household ceramic products should update design concept, pay attention to design creativity and lay a favorable foundation for the development of China's ceramic product market ${ }^{[1]}$.

\section{Importance of modern household ceramic product design innovation}

People's requirements for household ceramic products become higher and higher, so ceramic market changes continuously as consumers' requirements increase continuously. Household ceramic production enterprises need to keep product innovation in order to seek development in fierce market competitions, innovation is the sole way out for corporate development and progress and also the optimal approach for enterprises to operate for a long term. Meeting consumers' requirements for ceramic products and conducting corresponding product innovation can extend production life span of ceramic products, win market praise and finally achieve maximization of corporate economic benefit.

The innovation for design objective, design direction and design method of modern household ceramic products can fundamentally achieve corresponding product value, including economic value and aesthetic value. Innovation of household ceramic products makes traditional ceramic products own art culture and certain humanization. On this basis, traditional ceramic products own individual culture and fashion. Modern household ceramic products have certain differences with traditional ceramic products. Modern household ceramic products are not just ceramic products or household products, but also partial to art works. They are placed on bookcase and dining-tables of modern homes ad own certain culture nature. Modern innovative household ceramic products can further enrich people's spiritual pursuit and promote development and progress of consumption and ceramic market.

Household ceramic manufacturing enterprises can boost market competitiveness of their products through product design innovation and promote them to occupy a position in fierce market competitions. The combination of manual production technique of traditional ceramic products with 
mechanical technique of modern product production can not merely enhance product production efficiency, but also achieve fashion and diversity of ceramic products. This to some extent promotes development of ceramic production, contributes to inheriting and carrying forward ceramics culture and boost international status of China's ceramic market.

\section{Development tendency of modern household ceramic products}

Application of advanced science and technology and fashionable design philosophy in design and production of modern household ceramic products makes China's household ceramic products gradually develop to new trend, and make them more practical and artistic and cater to consumers' requirements.

\section{Fusion of modern household ceramic product design and traditional art ceramic product design}

According to relevant researches, an increasing number of household ceramic products are used by common people and enrich people's spiritual life pursuit. To cater to the market and meet people's requirements for household ceramic products, designers of household ceramic products start to design the products more artistically so that household ceramic products can comply with people's spiritual pursuit and aesthetic pursuit and even satisfy decoration style of people's modern homes. The fashion and art of ceramic products stand out increasingly. Traditional ceramic products are mostly used for exhibition to enhance art atmosphere of homes. But, although modern household ceramic products enhance corresponding practicability, consumers also take into account of objectivity, aesthetic nature and exhibition of ceramic products in selection process. Currently, fusing design philosophy of household ceramic products and design philosophy of traditional ceramic products can more richly reflect design art culture and emotion of product designers as well as aesthetic view of designers and consumers so that household ceramic products can meet people's daily life and enrich spiritual pursuit ${ }^{[2]}$.

\section{Fusion of design innovation and creative design of household ceramics}

Different from traditional household ceramic product design, creative design method has been fused in household ceramic product design process in recent years. Fusion of ceramic shape design field and product creative design field can achieve innovative development of household ceramic product. Economic globalization promotes development and fusion of regional economic culture and culture in different fields. In recent years, product creative design is favored by an increasing number of ceramic product designers. Such method is gradually applied in design of household ceramic product design and improves production efficiency of household ceramic products to the largest extent.

\section{Application of experience design in household ceramic product design}

At present, experience design has occupied an important position in product design field and plays a crucial role in product production and operation. Experience design means designers take into account of consumers' consumption opinion and product expectation, make product design meet consumers' requirements so as to promote consumption in product design work. The concept of experience design derived from Experience Economy proposed by American economist ${ }^{[3]}$. In recent years, the application of experience design in household ceramic product design has promoted ceramic shape, practicability, diversity and surface texture of household ceramic products and made modern household ceramic products further adapt market demand, consumers' demand and own more all-round design idea and design objective.

\section{Design innovation of modern household ceramic products}

For modern household ceramic products, ceramic shape is the most important factor. The first selection standard of consumers is the shape of household ceramic products. After the shape complies with consumers' requirements, consumers will further consider effectiveness of household ceramic 
products. Hence, to innovate for modern household ceramic product design, the first task is to innovate for ceramic shape. It is the foundation of all innovations. To carry out design innovation of household ceramic products, designers should have their unique views on modern life and eyes to find beauty. Designers should fuse interest and art in life as well as art of beauty with modern household ceramic product design, apply new design idea, formulate new design objective and adopt new design method to seek a new development way for household ceramic product design.

\section{New design of material texture}

Modern household ceramic products are different from traditional ceramic products. Only ceramic materials are applied in traditional ceramic product production. But in innovative development process of modern household ceramic products, products production starts to contact other production materials. Typical materials include bamboo, metal material and timber as well as glass. Ceramic materials are fused with these materials. Household ceramic shape innovates through fuse of production materials. Such innovative approach can not just make shapes of ceramic products diversified, but also enhance functional effectiveness of household ceramic products and make them own ceramic product and practicability. During innovating for design of household ceramic products, designers should first take into account of texture of ceramic products, innovate for and change texture of ceramic products, enhance touch feeling of household ceramic products and corresponding friction force, and practically show surface effect of household ceramic products. At present, consumers' requirements for household ceramic products become higher and higher. They mainly have requirements for texture of ceramic products. Diversified innovative design of ceramic texture can make ceramic products own certain emotional art and fashion art. Hence, innovative household ceramic products comply with aesthetic view of modern people and the favor of modern consumer group. During innovating for texture of household ceramic products, ceramic plate design is typical. Usually, ceramic plate is produced through fusing ceramic material and heterogeneous materials. Designers design texture on the surface of ceramic plate, which can perfectly combine space feeling of fruit tray and corresponding texture dynamics to make them more aesthetic. Meanwhile, ceramic plate can be also displayed at home as art works to meet spiritual and artistic pursuit as well as rich art atmosphere.

\section{Innovation of application mode}

Traditional ceramic products mainly serve as art works. But modern household ceramic products change the application mode through continuous innovation study. Continuous development of science and technology and people's higher and higher requirements for ceramic products make designers start to study design innovation of modern household ceramic products and optimize them. In the application mode innovation of household ceramic product design, ceramic utensil is typical in life. Designers observe and analyze living habits and cup holding habits for ceramic utensil. According to different habits of different people, designers start to carry out design innovation of household ceramic utensil, change the shape and make different types of household ceramic utensils comply with different types of people ${ }^{[4]}$. This to some extent caters to consumers and makes ceramic utensil fully achieve functions of daily life. On this basis, the change in ceramic shape makes ceramic utensil increase interest. Such application mode application can seek new development way for modern household ceramic products.

\section{Innovation of material attribute variation}

China owns a ceramic culture history for thousands of years. A fixed mode is generated for design and production of ceramic products. Thus, it is hard to break through and innovate for design of household ceramic products. But in recent years, design proportion has been changed for household ceramic products and design texture has been updated. Meanwhile, design quantity sense has also innovated. In variation innovation of material attribute, ceramic vase design is typical. To change traditional and single ceramic material production, ceramic vase is made of soft materials. Ceramic vase is shown with a modern posture through the way of material attribute variation to meet 
consumers' requirements and expectation of ceramics. Designers combine cloth plasticity and household ceramic products to make the vase further own sense of art beauty and be used conveniently.

\section{Structure change innovation}

Except the above innovation methods, designers should focus on structure change innovation. Designers observe specific component elements during ceramic product design and analyze composition framework and element rules. Designers can redesign traditional composition elements to form new framework and show new structure and new shape of ceramic products. Ceramic vase is most commonly seen in ceramic products. Ceramic vase which is full of sense of art beauty is mainly composed of water, vase and flower. Designers change ceramic framework of traditional ceramic products, combine water and flower in the vast with ceramic vase. For such kind of vases, designers emboss water form on the vase and then engrave the flower in water. Through this design operation, water, flower and vase can be perfectly combined to form new modern visual art. This further enriches sense of beauty of ceramic products.

\section{Conclusions}

This paper mainly sets forth and analyzes the importance of design innovation of modern household ceramic products and studies development trend of ceramic product design. On this basis, this paper proposes corresponding innovative direction and modes. China owns ceramics culture for several thousand of years. Since modern people have higher pursuit for ceramic art, design innovation of household ceramic products has become a problem which needs to be solved urgently. Product design innovation can achieve practicability of household ceramic products to the largest extent, give them aesthetic nature and artistry and promote long-term sustainable development of Chinese household ceramic products.

\section{References}

[1] Chen Lei, On innovative application of ceramic art works in modern homes. Culture and Art Life Theory of Literature and Art, 2013(11):47-47.

[2] Zhang Shuru, Launch of integrating home furniture resource "New Zhongyuan Decoration Expert" with innovative group purchase mode. Ceramics, 2012(5):62.

[3] Wang Jing, Analysis of current situation and innovative development of ceramic mosaic decoration art. Business, 2013(16):382-382.

[4] Independent innovation of Chinese building material enterprises and home furniture brand development summit forum. Foshan Ceramics, 2011,21(7):I0005-I0006.

[5] Li Yanzu, Beauty of creation: art and culture of product design. Beijing: China Renmin University Press, 2000 